\title{
Evaluation of Phytochemicals from Malbranchea cinnamomea, a thermophilic fungi isolated from compost (vegetable waste compost)
}

\author{
Geetha. $M^{*}$ \\ Department of Botany, B.M.S College for women, Basavanagudi, Bengaluru-560004, India. \\ ${ }^{*}$ Corresponding author:m.geetha1288@gmail.com
}

Available online at: www.isroset.org

Received: 27/Nov/2018, Accepted: 02/Dec/2018, Online: 31/Dec/2018

\begin{abstract}
The study was conducted at Department of Botany, Bangalore University, Bengaluru. Vegetable wastes are created during harvesting, transportation, storage, marketing and processing. The mixed vegetable waste were collected from different markets and then composted in heaps and pits. Composting was done during the year 2013. The temperature of the compost were recorded and then the soil samples were collected during thermophilic stage in polythene bags and bought to the laboratory. Isolation was done on Potato Dextrose Agar media (PDA) following serial dilution method and cultures were purified on PDA. The present study was carried out to evaluate the presence of phytochemicals from the isolated thermophilic fungi namely Malbranchea cinnamomea. Then the phytochemicals like totalphenols and flavonoids were estimated or analysed both qualitatively and quantitatively following standard procedure. In conclusion, the culture filtrate of Malbranchea cinnamomea has an ability to produce the phytochemicals. Among the phytochemicals the total phenols was maximum than tannins and flavonoids.
\end{abstract}

Key words: Flavonoids, Malbranchea cinnamomea, Thermophilic fungi, Tannins, Total phenol, Vegetable waste compost.

\section{INTRODUCTION}

Fungi are one among the most widely distributed organisms on earth [1]. Among the eukaryotes, only thermophilic fungi have the exceptional ability to grow at a high temperature $50-60^{\circ} \mathrm{C}$ [2]. The thermophilic fungi are those which have the maximum temperature for growth at above $50{ }^{\circ} \mathrm{C}$ and minimum temperature for growth at or above $20{ }^{\circ} \mathrm{C}$. Their prevalence in the composts is explained on the basis that prolonged elevated temperature humid and aerobic conditions and supply of carbohydrate and nitrogen in the mass of organic matter favours the development of thermophilic microflora.

Many biological materials show active decomposition accompanied by rise in temperature and are considered suitable for composting such as agricultural by products, crop residues, animal wastes, vegetable market wastes, food processing wastes and municipal refuse [3].

During composting, thermophilic, thermotolerant and mesophilic micro-organisms decompose cellulose, hemicelluloses and lignin of substrates [4]. The composting process is an exothermal biological oxidation of organic matter carried out by the microbial populations or microorganisms.The heterogenous organic matter of the raw material is transformed after a suitable composting period into a stabilized end-product through partial mineralization and humification [5].

Composting is the biological conversion of solid organic waste into usable end products such as fertilizers, substrates for mushroom production and biogas. High organic matter content and biological activity make composts effective in a variety of applications [6].Fungi affect soil fertility, suppress plant diseases and promote mushroom growth [7].

Malbranchea cinnamomea is a thermophilic fungi isolated from market waste compost. Furthermore, the fungi are able to produce some phytochemicals.

\section{MATERIALS AND METHODS}

\section{Isolation}

Vegetable wastes (Cabbage, tomato and mixed vegetable) are collected from different markets in and around Bangalore and were brought to the Department of Botany Bangalore University Bangalore and composted in heaps and pits. The samples were collected during thermophilic state of composting $\left(50-55^{\circ} \mathrm{C}\right)$ in polythene bagsand used for further process. The dilution plate technique [8]was employed to isolate fungi from vegetable waste composts. The thermophilic fungi were isolated on Potato Dextrose Agar media(PDA). 


\section{Identification}

The culture were identified from Microbial Type Culture Collection Centre (MTCC, Chandigarh) as Malbrancheacinnamomea and deposited with reference number MTCC 12145.

\section{Culture characteristics.}

The genus Malbranchea, has a sclerotial conidioma, conidiophores reduced, hyaline, conidiogenous cells, thallic, arthic, conidia hyaline, in coiled chains, 1-celled.

Malbranchea cinnamomea is thermophilic, colonies appeared robust, almost filling the petridish, dense, thick, smooth, velvety, with coarse, creamy yellow tufts of hyphae. The colour is sulphur yellow with yellow to pink margin. Large deposits of dark brown exudates present, the medium turns dark brown to black. The arthroconidia are borne as curved or loosely coiled lateral branches arising from the broader vegetative hyphae, the conidia are cylindrical, often curved, thick walled, hyaline at first, later yellow 2.5-3.5 $\mu \mathrm{m}$ diameter

\section{Maintainence of culture}

The mother cultures were maintained on Potato Dextrose Agar (PDA) slants and stored at $4{ }^{\circ} \mathrm{C}$ and they were sub cultured once in 6 to 8 weeks.

\section{Cultivation and extraction of mycelia of fungi.}

Fungi were grown on PDA at $55^{\circ} \mathrm{C}$ for 7 days. The $250 \mathrm{ml}$ Erlenmeyer flask containing $100 \mathrm{ml}$ of liquid PDB (potato dextrose broth) medium were sterilized for 15 minutes at $121^{\circ} \mathrm{C}$. The media were inoculated with Malbranchea cinnamomea and incubated at $55^{\circ} \mathrm{Cfor} 5$ days. After the completion of incubation, mycelia are separated from the liquid medium by filtration and drying at $50{ }^{\circ} \mathrm{C}$. The dry mycelium was pulverized and extracted with ethanol $(1: 1(\mathrm{~V} / \mathrm{V}))$ three times. The supernatant was separated by centrifugation at 5000rpm for 10 minutes, fractions were pooled and ethanolic extract was concentrated under reduced pressure to yield the final extract. Alcoholic extract of the fungal species were stored in dark at $4^{\circ} \mathrm{C}$ before being used for the bioactivity test.

\section{Prelimnary qualitative phytochemicals screening}

The alcoholic extract of Malbranchea cinnamomea were checked or screened for the presence of the following secondary metabolites such as alkaloids, phenols, flavonoids, tannins and saponins by standard procedures $[9$, $10]$.

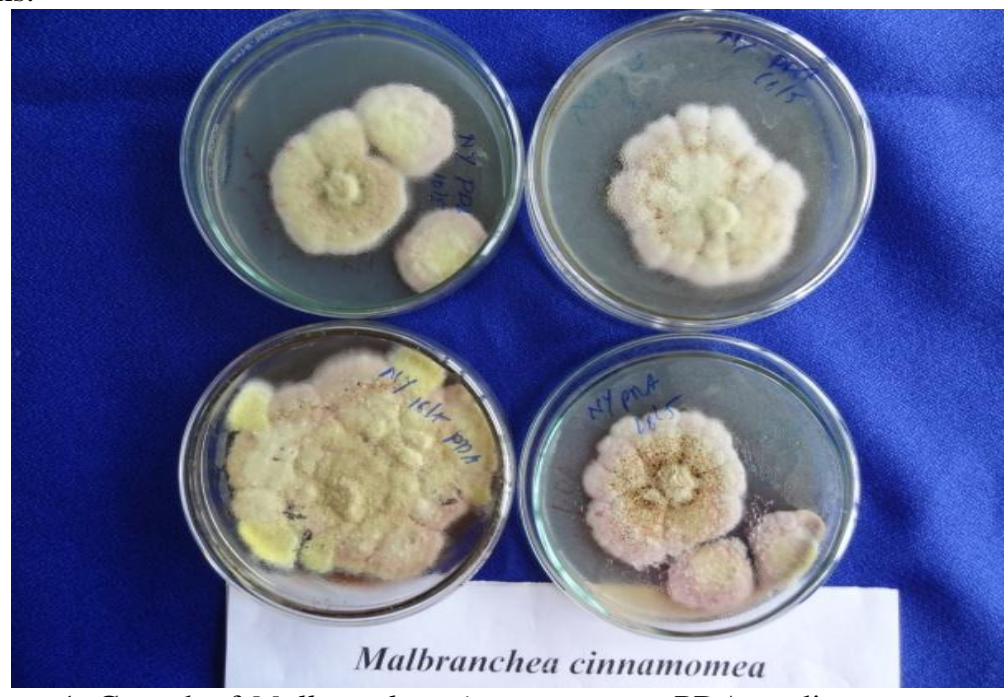

Figure-1: Growth of Malbranchea cinnamomea on PDA media.

\section{Phenols}

The extract is dissolved in $5 \mathrm{ml}$ of distilled. To this few drops of neutral $5 \%$ ferric chloride solution are added. A dark green colour indicates the presence of phenolic compounds.

\section{Tannins}

The fungal crude extract was treated with alcoholic Ferric chloride reagent. The bluish colour disappeared on addition of dilute sulphuric acid followed by the formation of yellowish brown precipitate indicated the presence of tannins.

\section{Saponins}

The presence of saponins were determined by froth test. The crude dry powder of the fungal extract was vigorously shaken with distilled water and was allowed to stand for 10 minutes. Appearance of no froth indicated the absence of saponins and stable froth indicated the presence of saponins.

\section{Quantitative estimation of phytochemicals \\ Total Phenolic content}

The total phenolic contents in the extract were determined according to the Folin-Ciocalteu method of [11]. To $1 \mathrm{ml}$ of ethanolic extracts, $2 \mathrm{ml}$ of $7.5 \%$ (W/V) sodium carbonate solution was added and vortexed vigorously. After $5 \mathrm{~min}$, 
$1 \mathrm{ml}$ of 1:10 diluted folin-ciocalteu phenol reagent was added and vortexed again. Procedure for above was followed for the standard solution of gallic acid. The test tubes were incubated at room temperature for 30 minutes and the absorbance was measured at $765 \mathrm{~nm}$ by using spectrophotometer (Elico). The total phenolic content in the extracts were expressed as gallic acid equivalent in $\mathrm{mg} / \mathrm{g}$ (GAE mg/g extract).

\section{Total Flavonoid content}

Total flavonoid content was determined according to [12]. The fungal extract $(250 \mu \mathrm{l})$ was mixed with distilled water $(1.25 \mathrm{ml})$ and Sodium nitrate solution $(5 \%, 75 \mu \mathrm{l})$. After 5 minutes the $\mathrm{AlCl}_{3}$ solution $(10 \% 150 \mu \mathrm{l})$ was added to the mixture. The solution was mixed well and the intensity of the pink colour was measured at 510nm against blank. The content of the flavanoid was calculated on the basis of the calibration curve of quercetin and the results were expressed as $\mathrm{mg}$ of quercetin equivalents per $\mathrm{g}$ of extract.

\section{Tannins}

The Tannin content was determined by [13]. $1 \mathrm{ml}$ of different aliquots of sample or standard, $5 \mathrm{ml}$ of Folin denis reagent was added, $10 \mathrm{ml}$ of sodium carbonate solution and diluted to $10 \mathrm{ml}$ with distilled water and shaked well and read at $700 \mathrm{~nm}$ after 30 minutes against reagent as blank. The content of tannins was calculated on the basis of the calibration curve of tannic acid and the results were expressed as mg of tannic acid equivalent to per $\mathrm{g}$ of extract.

\section{RESULTS}

The total phenol content of fungal crude extract was found to be $4.98 \mathrm{mg} \mathrm{GAE} / \mathrm{g}$.

The total flavonoid content of the fungi was found to be 3.54 mg Quercetin Equivalent/ g of extract.

The tannin content of fungi was found to be $4.78 \mathrm{mg} / \mathrm{g}$ Tannic acid.

\section{DISCUSSION}

In this study the thermophilic fungi were isolated from vegetable waste compost. Malbranchea cinnamomea were selected as the result shown was good. In the present study the fungi was identified as Malbranchea cinnamomea by MTCC.

The phytochemical analysis was carried out for the identified Malbranchea cinnamomea. The Malbranchea cinnamomea showed the presence of different phytochemicals such as phenolic compounds, tannins, alkaloids and flavonoids.

There are many bioactive compounds observed in the Penicillium sp. Our results are similar to the available reports of Nameirakpam Nirjanta Devi et al. 2012 [14].
Major natural products of secondary metabolism in plants and fungi are phenolic compounds. Phenol and flavonoid compounds have been reported to possess different bioactivities [15].

Alcoholic extract of Malbranchea cinnamomea showed higher phenolic and flavonoid content. It was found that total phenolic content of Penicillium granulatum was $7.01 \mathrm{mg}$ GAE/g, while in endophytic Penicillium sp was only $1 \mathrm{mg}$ GAE/g $[16,17]$.

\section{CONCLUSION}

Malbranchea cinnamomea has an ability to produce various secondary metabolites which will be useful for various purposes. So it could be recommended as an organism of pharmaceutical importance.

\section{ACKNOWLEDGEMENTS}

The authors are grateful to DST for providing financial support under PURSE Programme, and also laboratory facilities provided by Department of Botany, Bangalore University, Bangalore, India.

\section{REFERENCES}

[1]. Chinju Merin Abraham, Soumya Prasad. "Prelimnary phytochemical screening and antifungal activity of Bililbi and papaya leaf extract on fungal pathogens", International Journal of scientific Research in Biological Sciences, Vol 5, Issue 4, pp.97$102,2018$.

[2].D.G Cooney and R. Emerson,"Thermophilic fungi. An account of their Biology, activities and classification.", W.H Freemanand co., San Francisco, calif, 1964.

[3].S.S Yang,"Development and application potential of biofertilizer"s. AgricBiotechnolIndust Quart, Vol.4, pp. 9-17,2005.

[4].S.S Yang, Chen K.S. "Application of thermophilic microbes for preparing biofertilizers", Plant Protect Bull Spec Public New. Vol.5, pp. 267-291, 2003

[5].S.S Yang, 'Preparation and characterization of compost”, J Biomass Energy Soc China,vol.16, pp.47-62, 1997.

[6].R. Alexander,"Compost markets grow with environmental applications", BiocycleMagazine, March 1999: pp. 43-44.

[7]. G. Straatsma, R.A. Samson,"Taxonomy of Scytalidium thermophilum, an important thermophilic fungus in mushroom compost”, Mycol Res, vol. 97, pp.321-328,1993.

[8]. D. Parkinson, T. R.G Gray and S.T Williams,"Isolation of microorganisms. In: methods for studying the ecology of soil microorganisms", IBP Handbook No.19, Blackwell, London. pp. 36-55, 1991.

[9].Y. Maniyar, P.Bhixavatimath, "Evaluation of the hypoglycaemic and hypolipidaemic activities of the aqueous extract of the leaves of Ixoracoccinealinn in Diabetic rats",.J.ClinDiagn Res. Vol.5, Issue.7, pp. 1381-1384,2011.

[10]. S.MHandunnetti, R.R Kumara, S.A Deraniyagala , W.D Ratnasooriya,"Anti-inflammatory activity of Ixora coccinea methanolic leaf extract”,Pharmacogn Res .Vol. 1, issue.2, pp. 8090,2009 . 
[11].V. L Singleton and J .A Rossi," Colorimetry of total phenolics with phosphomolybdic-phosphotungstic acid reagents" ,Am.J.EnolVitic. Vol.16, pp.144-158, 1965.

[12].L Barros, Ferreira M.J Queiros B Ferreira C.F.R, Baptista P,“Total phenols, ascorbic acid $\beta$-Carotene and lycopene in Portuguese wild edible mushrooms and their antioxidant activities", Food Chemistry. Vol.103, pp.413-419, 2007.

[13]. Rajeev Singh, Pavan kumar Verma and Gagandeep Singh. "Total phenolic, flavonoids and tannin content in different extract of Artemisia absiuthium", J Intercult ethanopharmacology. Vol.1,Issue .2,pp.101-104, 2012.

[14].Nameirakpam Nirjantadevi, J.JohnPrabhakaran, FeminaWahab, "Phytochemicalanalysis and enzyme analysis of endophytic fungi from Centellaasiatica", Asian Pacific Journal of tropical Biomedicine. Pp. 51280-51284,2012.

[15]. W.Y Huang, Y.Z Cai, .Y Zhang, "Natural phenolic compounds from medicinal herbs and dietary palnts:potential use for cancer prevention”, Nutr Cancer. Vol.62, Issue.1, pp.1-20,2010.

[16]. P. Chandra., D.S Arora,"Optimization ofantioxidant potential of Penicilliumgranulatum. Bainer by statistical approaches", ISRN Microbiol.2012.

[17]. N.K, Murthy,K.C Pushpalatha, C.G Joshi,“Antioxidant activity and phytochemical analysis of endophytic fungi isolated from Lobelia nicotianafolia.", J.chem.Pharm. Res.Vol. 3, pp.218-225, 2011.

\section{AUTHORS PROFILE}

Dr.M.Geetha pursued Master of Science and Ph.D. in Botany from Bangalore University, Bengaluru and currently working as a lecturer in the Department of Botany, B.M.S College for Women, Basavanagudi, Bengaluru. She has attended

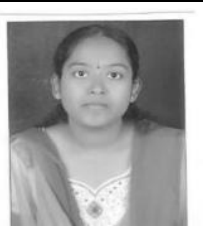
more than 10 Conferences, National and International levels, workshop and training programme and published 5 research papers. Her main research work focuses on Microbiology, Biofertilizers and Organic farming. She has 5 years of teaching experience and 4 years of research experience. 